\title{
The Influence of Personality Traits, Motivation, Learner Autonomy and Leadership Style Towards Job Performance
}

Che Mohd Syaharuddin Che Cob, Fazreena Mansor, Syahida Abd Aziz

To Link this Article: http://dx.doi.org/10.6007/IJARBSS/v11-i4/9747

DOI:10.6007/IJARBSS/v11-i4/9747

Received: 19 February 2021, Revised: 20 March 2021, Accepted: 05 April 2021

Published Online: 26 April 2021

In-Text Citation: (Cob et al., 2021)

To Cite this Article: Cob, C. M. S. C., Mansor, F., \& Aziz, S. A. (2021). The Influence of Personality Traits, Motivation, Learner Autonomy and Leadership Style Towards Job Performance. International Journal of Academic Research in Business and Social Sciences, 11(4), 941-954.

\section{Copyright: @ 2021 The Author(s)}

Published by Human Resource Management Academic Research Society (www.hrmars.com)

This article is published under the Creative Commons Attribution (CC BY 4.0) license. Anyone may reproduce, distribute, translate and create derivative works of this article (for both commercial and non-commercial purposes), subject to full attribution to the original publication and authors. The full terms of this license may be seen at: http://creativecommons.org/licences/by/4.0/legalcode

Vol. 11, No. 4, 2021, Pg. 941 - 954

Full Terms \& Conditions of access and use can be found at http://hrmars.com/index.php/pages/detail/publication-ethics 


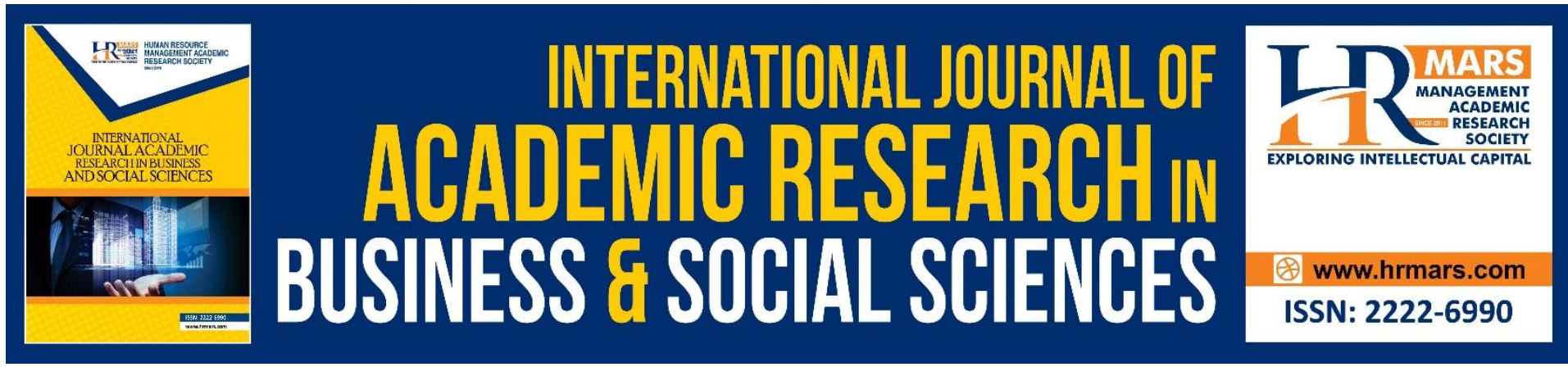

\title{
The Influence of Personality Traits, Motivation, Learner Autonomy and Leadership Style Towards Job Performance
}

\section{Che Mohd Syaharuddin Che Cob ${ }^{1}$, Fazreena Mansor², Syahida Abd Aziz ${ }^{3}$}

Universiti Teknologi MARA Kelantan, Machang Campus, ${ }^{1}$ Universiti Teknologi MARA Pahang, Raub Campus, ${ }^{2}$ Universiti Teknologi MARA Kedah³, Malaysia

Email: syaha793@uitm.edu.my

\begin{abstract}
In the current context of organizations, personality traits, motivation, learner autonomy, and leadership style are some of the important antecedents that influence job performances. However, the disclosure of job performance among public servants through mass media such as delays in the delivery of services, inefficiency in performing jobs, dissatisfaction over service quality, dissatisfaction regarding accountability and integrity become a restriction in the service delivery system. Therefore, this study examines the influence of personality traits, motivation, learner autonomy, and leadership style on job performance. This study also aims to determine the most influential factors on job performance. The population in this study included 16,960 staff of Universiti Teknologi MARA (UiTM), with a sample of 600 respondents, using the stratified sampling method. The study is guided by an adapted ten-point Likert Interval Scale structured questionnaire as the main instrument used in collecting the data. Furthermore, the analysis of data was undertaken by using Confirmatory Factor Analysis (CFA) procedures and Structural Equation Model (SEM) utilizing AMOS software. The findings show that personality trait, motivation, learner autonomy, and leadership style contributes 37 percentages to job performance. The analysis of SEM revealed that there is a significant relationship between personality traits, motivation, learner autonomy, and leadership style on job performance. Besides that, these research findings show that employee motivation is the most significant factor that influences job performance. The study proves that individual job performance can be improved if the combination of the personality traits, motivation, learner autonomy, and leadership style on job performance is in a sound state. Therefore, implications of the findings, potential limitations, and directions for future research are also discussed.
\end{abstract}

Keywords: Job Performance, Personality Traits, Employee Motivation, Learner Autonomy, and Leadership Style

\section{Introduction}

The employee is a valuable asset of the organization. The success or failure of an organization depends heavily on its job performance (Man \& Lau, 2005, Ramayah, et al., 2016). This means 
that high performers of employees lead to better organizational success. Besides, job performance is an important mechanism for developing human resource skills and employee development (Huzaime \& Latiff, 2011). Hence, for an organization regardless of any sector, job performance was identified and had a relationship with the organizations' success (Campbell, 1990; Schmidt \& Hunter, 1992). Through the achievement of job performance can be seen to the extent that management successfully meets the needs of the organization's workforce, especially from the contributions they have made.

Several models of job performance taxonomy in past literature highlight and explain the expected value of behavior based on various categories. According to Motowidlo (2012), job satisfaction is one of the core constructs in management and is the most widely studied variable in organizational behavior. Previous research has shown that various challenges faced by organizations demanding structural changes and paradigm shifts to ensure their existence remain relevant. In other words, researches on job performance have developed significant interest among researchers worldwide and it has become a universal reality in human resource management studies, that performance and productivity are significantly related. Thus, it must be at a certain level in order to achieve those goals. This is because job performance is an important construct in developing the effectiveness and success of the organization. However, organizations may find it difficult to distinguish between performers and non-performers. In view of this, therefore, the study on determinants of job performance needs to be clarified to ensure the continuity of the organization. Therefore, the objectives of this study are to examine the influence of personality traits, motivation, learner autonomy, and leadership style on job performance. Besides, to determine the most influential factors on job performance.

\section{Literature Review Job Performance}

Job performance is defined by Motowidlo (2012) as the total anticipated value from employees' behaviors agreed within the period of time. Thus, job performance can be understood based on their categories either according to the content of the behavior, related organization, motivational antecedent, or other antecedents such as ability and personality traits. Moreover, Borman \& Motowidlo (1997) discuss job performance into two distinct elements, which are; contextual performance, and task performance. Contextual performance is not directly related to the core business of the organization. Instead, engage with matters related to the well-being of the social environment and organizational psychology. Contextual performance includes activities such as helping and collaborating with other employees. Accordingly, adhering to the rules and procedures of the organization, remaining motivated to complete tasks, and offering to do work that is not formally written is the responsibility of the individual. In addition, this theory also focuses on individual differences as a factor inherent in job performance. However, task performance is directly related to the core business or activities of an organization. It is divided into two types; the first type of task performance involves the activity of converting raw materials into goods and services that are the product of an organization. The second type of task performance is to contain activities that serve the core business as well as maintain the core needs. Thus, job performance can help individuals to realize organizational goals. This is why the employee job performance is becoming increasingly important, as it is the main driver in leading the ability of the organization to plan efficiently and effectively (Mokhtar Abas, 2006). Meanwhile, 
Huzaime \& Latif, 2011 discuss job performance as an important mechanism for developing human resource skills. Therefore, job performance is an important indicator in determining the success and achievement of the organization.

\section{Personality Traits and Job Performance}

Costa and McCrae (2008) defined personality as "enduring emotional, interpersonal, experiential, attitudinal, and motivational style that explains individual behaviors in different situations." Besides, personality traits can be seen as the engine which drives behavior of employees (Barrick \& Mountt 1991). This is because, if the personality traits of an employee in a sound stated, it can lead to increased productivity and help the organization to function more efficiently. The personality traits which are openness, conscientiousness extraversion, agreeableness and neuroticism have been categorized as the Big Five Personality (McCrae and Costa, 2008; Barrick \& Mount, 1991).

Mahlamäki, Rintamäki, \& Rajah (2019) found that all the five personality traits drive behavior of employees. Moreover, Sudiantha, Armanu and Troena (2017) claimed that of all five personality traits, conscientiousness and agreeableness make the most efficient employees. This is in line with Bhatia \& Rawat (2019) found that personality traits such as extraversion, neuroticism, openness had significant positive impacts on job performance and agreeableness; consciousness had significant negative impact on job performance. Thus, it is suggested the potential relationship between the famous Five-Factor Model and overall job performance. More specifically, researchers have been motivated to discover the factual relationship among big Five- personality traits and their direct impact on employee job performance.

\section{Motivation and Job Performance}

Kreitner and Kninicki (1998) defined motivation at the workplace as a psychological process that provides direction and intensity, to achieve organizational goals. While Robbins (2005), on the other hand, defines motivation as a set of energetic forces that will influence the workrelated behaviour. Hence, from a human resource perspective only motivated employees are prepared to work hard. Both definitions prove that motivation is the driving force to guide employees towards the achievement of organizational goals (Devito et al., 2016). One of the factors that can increase the morale of employees to work is the existence of a strong employee motivation Ahmad (2020). Without a high level of motivation, job performance of employees will be reduced and it's likely the organization will fall to reaching their goals. Thus, motivation is a very important factor that contributes to employee's job performance (Mohd Said et al., 2015; Ali et al., 2020; Syamsir, 2020).

\section{Learner Autonomy and Job Performance}

The phrase 'learner autonomy' or 'autonomous learning' was coined by educational guru who defined it as the "learner's ability to take charge of his or her own learning" (Holec, 1981). However, human resource practitioners believe that to differentiate learner autonomy from formal training and development in which learners can and should take charge of their learning. Hence we need to consider a more complex conceptualization.

From a human resource management perspective, learner autonomy encompasses several other learning concepts that have been studied in the training and development and 
education domain (Ford, 2018). The terms commonly used including employee development, self-development, self-directed learning, workplace learning, and informal learning (Daryoush et al., 2013). Hence, most researchers suggested the potential relationship between learner autonomy and job performance in workplace (Johari \& Zulkarnain, 2018; Ellingson \& Noe, 2017; Merriam \& Baumgartner, 2020; Ford, Baldwin \& Prasad, 2018; Vassou, 2017; Klimas, 2017; Daryoush et al., 2013; Bromfield 2002).

\section{Leadership Style and Job Performance}

According to Bass \& Avolio (1994), there were three basic leadership styles consisting of transformational, transactional, and laissez-faire. Transformational leadership is seen as effective leadership in making and managing change in an educational institution. According to Guhr \& Breitner (2019), leaders who practice transformational leadership are those who always prepare themselves in giving and raising awareness and enthusiasm to their followers about the importance of improving the achievement, self-actualization, and goals of their organization.

Transformational leadership is a characteristic of leaders that focuses on the development of the individual needs of followers. They try to change the views of their followers on some issues by helping them see old problems in new ways. Besides, transactional leadership focuses on rewards and punishment to motivate their subordinates (Bass \& Avolio, 1994). Laissez-faire leadership style being indecisive decisions and can result in poor crisis management. Studies by Guhr, Breitner (2019) show leadership style (transformational and transactional leadership style) can increase individual job performance and lasting influence on organizational performance. Researchers Bass et al., (2003) suggest leadership style as a complement to understanding the employee job performance and the effectiveness of an organization.

Based on the discussion, four hypotheses were suggested for this study and the research framework displayed in Figure 1.

H1: Personality Trait has a positive and significant relationship with job performance.

H2: Motivation has a positive and significant relationship with job performance.

H3: Learner Autonomy has a positive and significant relationship with job performance. H4: Leadership Styles has a positive and significant relationship with job performance.

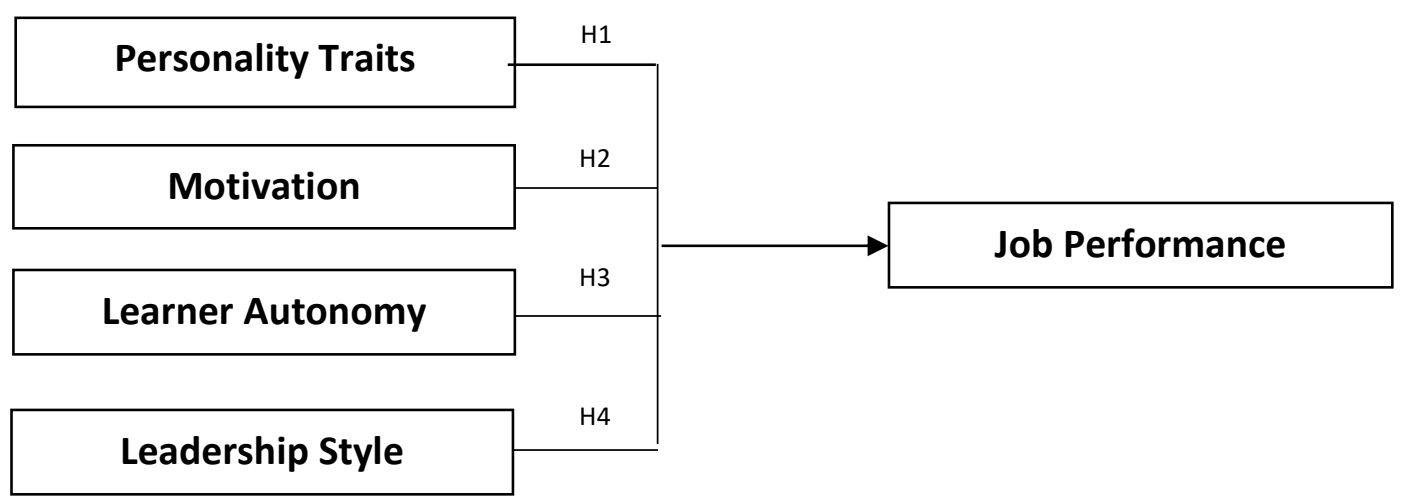

Figure 1: The Hypothesized Model of Job Performance 


\section{Methodology \\ Sample and Data}

Our empirical data has been conducted based on data from a survey carried out among staff of Universiti Teknologi MARA (UiTM). The population in this study included 16,960 staff. Thus, the appropriate sample size for this study involved 600 staff (Sekaran, 2003). A total of 600 questionnaires were distributed and we received replies from 600 staff. After reviewing each of them, we proceed to the removal of the questionnaires on which no questions have been answered. Therefore, we collected 500 valid questionnaires (response rate of $83 \%$ ) of staff. The probability technique (stratified random sampling) was applied in this study because under probability sampling the subjects of the population get an equal opportunity to be selected as a representative sample, the results in unbiased, and hypothesis developed can be tested (Sekaran, 2003).

\section{Variables and Measurement}

The study is guided by an adapted ten-point Likert Interval Scale structured questionnaires as the main instrument used in collecting the data. Item statements are measured as subjective estimates using a ten-point Likert scale (with 1=strongly unimportant to $10=$ strongly important. In order to evaluate job performance, employee motivation, learner autonomy, and leadership styles researcher used the questionnaires of job performance developed by Borman \& Motowidlo (1997) 14 items; the questionnaires of traits personality developed by Goldberg et al., (2006) 29 items; the questionnaires of employee motivation developed by Bliss (2008) 10 items; the questionnaires of learner autonomy developed by Confessore \& Park (2004) 28 items and the questionnaires of Multifactor Leadership Questionnaires (MLQ) developed by Bass \& Avolio (1990) 28 items. Furthermore, the analysis of data was undertaken by using Confirmatory Factor Analysis (CFA) procedures and Structural Equation Model (SEM) utilizing AMOS software.

\section{Findings \& Discussion}

This study interest to determine the influence of personality traits, motivation, learner autonomy, and leadership styles on job performance. The results of the descriptive analysis of this study display in Table 1 below. 
INTERNATIONAL JOURNAL OF ACADEMIC RESEARCH IN BUSINESS AND SOCIAL SCIENCES

Vol. 11, No. 4, 2021, E-ISSN: 2222-6990 ㄷ 2021 HRMARS

Table 1. Descriptive Analysis of Respondents ( $N=600$ )

\begin{tabular}{|c|c|c|c|}
\hline Items & Categories & Frequency & Percent \\
\hline \multirow[t]{2}{*}{ Gender of Respondents } & Male & 210 & 42 \\
\hline & Female & 290 & 58 \\
\hline \multirow[t]{5}{*}{$\begin{array}{l}\text { The Current Age of } \\
\text { Respondents }\end{array}$} & 25 or below & 32 & 6.4 \\
\hline & $26-35$ & 128 & 25.6 \\
\hline & $36-45$ & 140 & 28 \\
\hline & 46-55 & 140 & 28 \\
\hline & 56 or above & 60 & 12 \\
\hline \multirow[t]{6}{*}{$\begin{array}{l}\text { Education Attainment of } \\
\text { Respondents }\end{array}$} & SRP/PMR & 29 & 5.8 \\
\hline & SPM/MCE & 93 & 18.6 \\
\hline & Diploma & 61 & 12.2 \\
\hline & Degree & 177 & 35.4 \\
\hline & Master & 140 & 28 \\
\hline & PhD/DBA & 100 & 20 \\
\hline \multirow[t]{6}{*}{ Length of service } & 3 years or less & 22 & 4.4 \\
\hline & 3 - 6 years & 103 & 20.6 \\
\hline & $7-10$ years & 110 & 22 \\
\hline & $11-14$ years & 140 & 28 \\
\hline & $15-18$ years & 60 & 12 \\
\hline & $\begin{array}{c}18 \text { years or } \\
\text { more }\end{array}$ & 65 & 13 \\
\hline
\end{tabular}

The multiple linear regression analysis with AMOS is applied because this analysis is only addressed on the exogenous construct without taking into consideration another construct. This model was analyzed by the individual Confirmatory Factor Analysis (CFA) method to determine their factor loading and fitness indexes. According to Awang (2015), the individual CFA is preferred in this study due to the complexity of the model that has many items to be measured. The structural model for job performance is displayed in Figure 2.

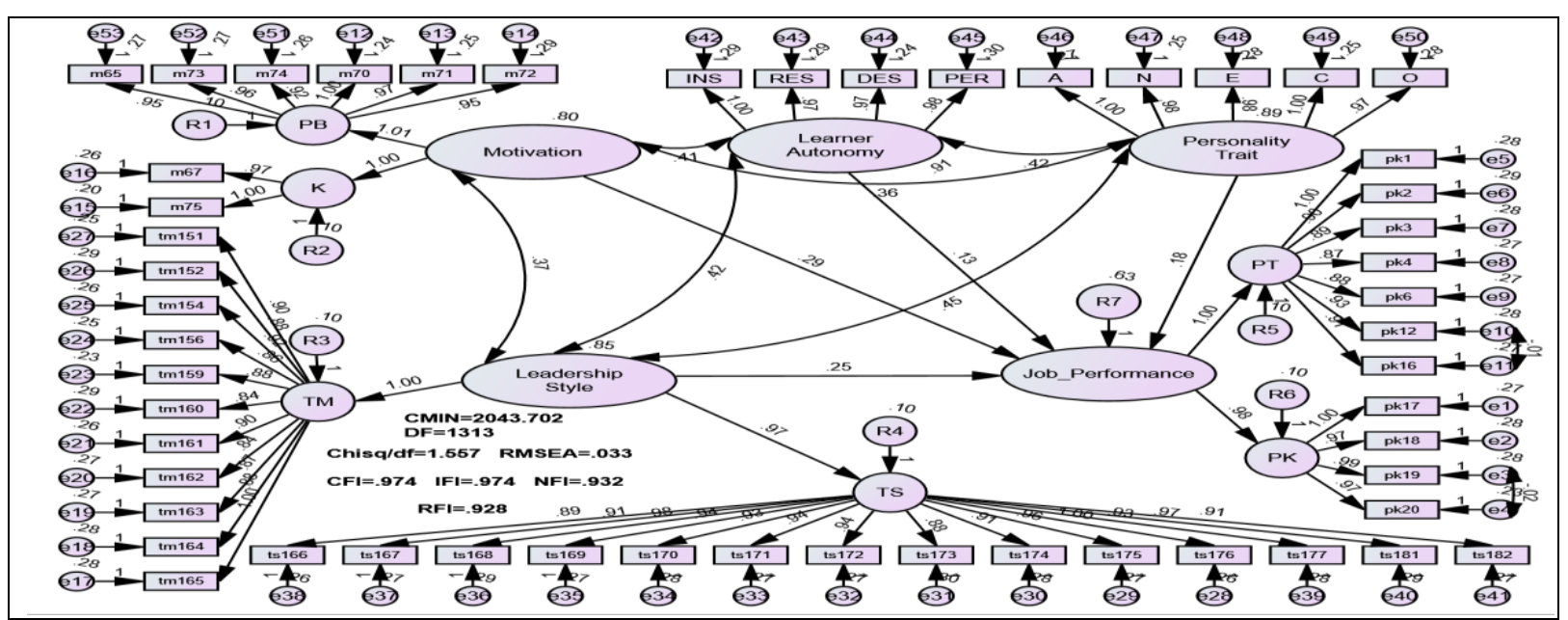

Figure 2. Structural Model for Job Performance 
Table 2 below showed the normality results of this finding. All variables are satisfied since the value of skewness falls in the range between -1.5 to 1.5 (Awang, 2015). Meanwhile, the multivariate kurtosis also is below 50.0 indicating that normality existed for this model. Therefore, this model is admissible for hypothesis purposes. This is followed by Table 3 that displayed the regression weights of the determinant factors on job performance.

Table 2. Assessment of normality

\begin{tabular}{|c|c|c|c|c|c|c|}
\hline $\begin{array}{l}\text { Variabl } \\
\text { e }\end{array}$ & Min & Max & Skew & c.r. & Kurtosis & c.r. \\
\hline $\mathrm{m} 65$ & 3.000 & 8.000 & -.011 & -.100 & -.178 & -.814 \\
\hline $\mathrm{m} 73$ & 2.000 & 9.000 & .009 & .080 & .265 & 1.211 \\
\hline $\mathrm{m} 74$ & 3.000 & 9.000 & .194 & 1.775 & -.267 & -1.220 \\
\hline $\mathrm{O}$ & 2.000 & 8.000 & .162 & 1.478 & -.115 & -.526 \\
\hline C & 3.000 & 9.000 & .067 & .607 & -.160 & -.730 \\
\hline$E$ & 3.000 & 10.000 & -.062 & -.567 & .002 & .009 \\
\hline$N$ & 3.000 & 9.000 & .060 & .552 & -.087 & -.398 \\
\hline A & 2.000 & 8.000 & -.048 & -.441 & .044 & .201 \\
\hline PER & -1.000 & 6.000 & -.161 & -1.467 & .473 & 2.160 \\
\hline DES & -1.000 & 6.000 & -.380 & -3.472 & .864 & 3.945 \\
\hline RES & 1.000 & 8.000 & -.282 & -2.573 & .327 & 1.492 \\
\hline INS & 1.000 & 8.000 & -.161 & -1.466 & .034 & .156 \\
\hline ts182 & 2.000 & 8.000 & -.052 & -.477 & .071 & .322 \\
\hline ts181 & 2.000 & 10.000 & .073 & .669 & .636 & 2.904 \\
\hline ts177 & 3.000 & 9.000 & -.016 & -.143 & .160 & .731 \\
\hline ts166 & 3.000 & 9.000 & .057 & .517 & .142 & .646 \\
\hline ts167 & 2.000 & 8.000 & -.153 & -1.392 & -.015 & -.069 \\
\hline ts168 & 2.000 & 9.000 & -.015 & -.133 & .000 & -.002 \\
\hline ts169 & 1.000 & 8.000 & -.149 & -1.358 & .335 & 1.530 \\
\hline ts170 & 1.000 & 7.000 & -.010 & -.092 & .157 & .715 \\
\hline ts171 & 1.000 & 6.000 & -.015 & -.135 & -.358 & -1.635 \\
\hline ts172 & .000 & 6.000 & -.018 & -.167 & .217 & .992 \\
\hline ts173 & .000 & 6.000 & -.103 & -.942 & .013 & .060 \\
\hline ts174 & 1.000 & 8.000 & .073 & .669 & .121 & .554 \\
\hline ts175 & 3.000 & 9.000 & -.013 & -.119 & .019 & .087 \\
\hline ts176 & 3.000 & 8.000 & -.124 & -1.128 & -.245 & -1.119 \\
\hline tm151 & 1.000 & 7.000 & .023 & .213 & .210 & .959 \\
\hline $\operatorname{tm} 152$ & .000 & 6.000 & -.186 & -1.702 & .178 & .812 \\
\hline tm154 & .000 & 6.000 & .000 & .004 & .075 & .341 \\
\hline $\operatorname{tm} 156$ & 1.000 & 8.000 & .001 & .008 & .374 & 1.706 \\
\hline tm159 & 2.000 & 8.000 & -.186 & -1.702 & .751 & 3.426 \\
\hline $\operatorname{tm} 160$ & 3.000 & 8.000 & -.170 & -1.547 & -.123 & -.563 \\
\hline $\operatorname{tm} 161$ & 3.000 & 9.000 & -.116 & -1.062 & -.035 & -.162 \\
\hline $\operatorname{tm} 162$ & 3.000 & 9.000 & .022 & .202 & .354 & 1.614 \\
\hline
\end{tabular}




$\begin{array}{lllllll}\text { tm163 } & 2.000 & 8.000 & -.093 & -.852 & .015 & .071 \\ \text { tm164 } & 2.000 & 8.000 & -.010 & -.094 & -.177 & -.806 \\ \text { tm165 } & 2.000 & 8.000 & -.185 & -1.692 & .113 & .516 \\ \text { m67 } & 2.000 & 8.000 & .077 & .705 & -.346 & -1.578 \\ \text { m75 } & 2.000 & 8.000 & .118 & 1.079 & .040 & .184 \\ \text { m72 } & 2.000 & 8.000 & -.019 & -.171 & .190 & .868 \\ \text { m71 } & 2.000 & 8.000 & -.019 & -.178 & .100 & .458 \\ \text { m70 } & 3.000 & 9.000 & .084 & .770 & .104 & .475 \\ \text { pk16 } & 2.000 & 8.000 & -.060 & -.548 & .076 & .346 \\ \text { pk7 } & 3.000 & 9.000 & -.033 & -.303 & -.379 & -1.731 \\ \text { pk6 } & 3.000 & 9.000 & .036 & .328 & -.089 & -.406 \\ \text { pk4 } & 2.000 & 8.000 & .003 & .026 & -.102 & -.464 \\ \text { pk3 } & 2.000 & 9.000 & .012 & .114 & .082 & .375 \\ \text { pk2 } & 3.000 & 9.000 & -.004 & -.038 & -.044 & -.202 \\ \text { pk1 } & 3.000 & 9.000 & -.090 & -.819 & .010 & .045 \\ \text { pk20 } & 3.000 & 9.000 & .044 & .401 & -.060 & -.274 \\ \text { pk19 } & 2.000 & 9.000 & -.151 & -1.375 & .081 & .371 \\ \text { pk18 } & 1.000 & 8.000 & -.037 & -.341 & .140 & .640 \\ \text { pk17 } & .000 & 7.000 & -.169 & -1.538 & .095 & .435 \\ \text { Multiva } & & & & & 6.652 & .974 \\ \text { riate } & & & & & & \end{array}$

Table 3. Regression Weight Of Determinant Factors On Job Performance

\begin{tabular}{|c|c|c|c|c|c|c|c|}
\hline & & & Estimate & S.E. & C.R. & $\mathbf{P}$ & Result \\
\hline $\begin{array}{l}\text { Job } \\
\text { Performance }\end{array}$ & $<---$ & $\begin{array}{l}\text { Personality } \\
\text { Traits }\end{array}$ & .292 & .057 & 5.166 & $* * *$ & Significant \\
\hline $\begin{array}{l}\text { Job } \\
\text { Performance }\end{array}$ & $<---$ & Motivation & .127 & .053 & 2.401 & .016 & Significant \\
\hline $\begin{array}{l}\text { Job } \\
\text { Performance }\end{array}$ & $<--$ & $\begin{array}{l}\text { Learner } \\
\text { Autonomy }\end{array}$ & .179 & .053 & 3.362 & $* * *$ & Significant \\
\hline $\begin{array}{l}\text { Job } \\
\text { Performance }\end{array}$ & $<---$ & $\begin{array}{l}\text { Leadership } \\
\text { styles }\end{array}$ & .250 & .056 & 4.460 & $* * *$ & Significant \\
\hline
\end{tabular}

The Relationship between Personality Traits and Job Performance

From table 3 , the path coefficient of personality traits on job performance is 0.292 . This value indicates that for every one unit increase in employee motivation, its effect would contribute 0.292 unit increase in job performance. The regression weight estimate of 0.292 has a standard error of 0.057 . The critical ratio is shown as 5.166 standard errors above zero. The probability of getting a critical ratio of 5.166 in an absolute value is 0.000 . Based on the above, the hypothesis suggested that higher employee motivation will report possessing greater job performance is supported.

The Relationship between Motivation and Job Performance

From table 3 , the path coefficient of learner autonomy on job performance is 0.127 . This 
value indicates that for every one unit increases in motivation, its effect would contribute 0.127 unit increase in job performance. The regression weight estimate of 0.127 has a standard error of 0.053 . The critical ratio is shown as 2.401 standard errors above zero. The probability of getting a critical ratio of 2.401 in an absolute value is 0.016 . Based on the above, the hypothesis suggested that higher learner autonomy will report possessing greater job performance is supported.

\section{The Relationship between Learner Autonomy and Job Performance}

From table 3 , the path coefficient of motivation on job performance is 0.179 . This value indicates that for every one unit increase in motivation, its effect would contribute 0.292 unit increase in job performance. The regression weight estimate of 0.292 has a standard error of 0.053 . The critical ratio is shown as 3.362 standard errors above zero. The probability of getting a critical ratio of 3.362 in an absolute value is 0.000 . Based on the above, the hypothesis suggested that job performance with good personality traits will report possessing greater job performance is supported.

\section{The Relationship between Leadership Styles and Job Performance}

From table 3 , the path coefficient of motivation on job performance is 0.250 . This value indicates that for every one unit increase in motivation, its effect would contribute 0.250 unit increase in job performance. The regression weight estimate of 0.250 has a standard error of 0.056 . The critical ratio is shown as 4.460 standard errors above zero. The probability of getting a critical ratio of 4.460 in an absolute value is 0.000 . Based on the above, the hypothesis suggested that leaders with good leadership style (transformational and transactional leadership styles) will report possessing greater job performance is supported.

\section{Discussion}

In this study, personality is explained by using a Big-Five model of personality, namely extraversion, agreeableness, openness to experience, neuroticism, and conscientiousness. From the results, it is found that this trait model of personality influences job performance among Universiti Teknologi MARA staff. This means that the Big-Five model of personality trait contributes to changes in job performance. This finding has been supported by the Study of Mehmood, Mehmood, and Siddique (2017), which shows that there is an influence between personality traits and job performance. The findings of this study also show that personality traits are predictors of job performance (Othman \& Fatimah, 2014). This is supported by the findings of the study by Ahmad, Ather, and Hussain (2014). De Jonng et al., (2019) showing that personality traits are one of the factors that influence job performance.

Motivation is set with two indicators, namely performance motivation and commitment. From the results, it is found that this model is significant in making assumptions about the influence between motivation and job performance of Universiti Teknologi MARA staff. This significant relationship means that the higher the motivation will result in higher job performance. Therefore, it is necessary to control the performance-driven motivational variables in order to create motivation to improve job performance. The findings of this study are in line with the opinion (Ali, 2020; Springer \& Gary Jon, 2011) that one of the ways management can improve staff work performance is through giving encouragement 
or motivation. Theoretically, this study is supported by the findings of a study by Maneetr \& Thirachaya, (2010) which shows that there is a relationship between motivation and job performance. Therefore, effective motivation needs to be implemented by Universiti Teknologi MARA management so that motivation is created and staff will work hard to achieve the set work performance. Furthermore, the findings of this study also explain the motivation of Universiti Teknologi MARA staff based on performance motivational aspects that will make them stronger to work with. Therefore, Universiti Teknologi MARA management needs to identify the real needs of employees based on motivational mechanisms at all levels of staff.

This study contributes to a new field of knowledge that is the concept of learner autonomy in the workplace. The findings of this study show that learner autonomy influences job performance. The influence of this learner autonomy refers to changes related to needs, emotions, instincts, motivations, intelligence that are 'invisible' and internal. In the context of this study, learner autonomy is measured through the constructs of desire, initiative persistence, and resourcefulness (Confessore \& Park, 2004). Furthermore, this study also shows that learner autonomy is a key indicator for individuals to be more high-achieving. This means that individuals with high learning autonomy have higher job performance. Accordingly, this study aims to propose a comprehensive definition and concept of learner autonomy and a theoretical position for further study in the field of organizational psychology and its relevance to the concept of learner autonomy at the workplace. The results of this study are in line with the study by Ellingson et al, (2017) who showed that there is a relationship between learner autonomy and job performance. when UiTM staff who have high learner autonomy tend to have high job performance. On the other hand, staff with low levels of learner autonomy tend to have low job performance. Researchers conclude that the job performance of Universiti Teknologi MARA staff is influenced by learner autonomy and this is in line with the theory of Planned Behavior (TPB) a high level of learning autonomy will encourage these staff to improve job performance. This is because staff with high learning autonomy will learn proactively. Indicators of high levels of learning autonomy are always eager to perform new tasks, proactive to innovate and strive to find the best way to perform tasks.

In this study leadership style refers to the leadership style of the leader towards achieving organizational goals. Leadership style is measured through employee perceptions of leaders through transformational and transactional leadership styles. From the results of hypothesis testing, it is found that this model is significant in making assumptions about the influence between leadership style and work performance of UiTM staff. The findings of this study are seen in line with the findings of previous studies. This significant positive relationship means that the better the leadership style of the leader the better the performance of the staff. This result shows that the leadership style factor contributes to the change in job performance. Through the leadership styles discussed, it can be concluded that transformational and transactional leadership styles are appropriate to use and influence the leadership pattern of the leader whether good and perfect or vice versa, inverted and make the situation ineffective. These findings have been supported by studies (Al-Malki et al., 2018) 


\section{Conclusion}

In light of the findings, the study proves that dimensions of personality traits, employee motivation, learner autonomy, and leadership style predict job performance among employees of Universiti Teknologi MARA (UiTM). Besides that, this research shows that employee motivation is the most significant factor that influences job performance. It is further concluded, learner autonomy represents one of only a handful in extant literature. Thus, the learner autonomy offers a novel perspective in the workplace. Therefore, the study proves that the model of job performance among employees of UiTM can be improved if the combination of the personality traits, motivation, learner autonomy, and leadership style on job performance are in a sound state. The model will serve as a basis for the management of UiTM to give special attention to employee motivation and learner autonomy. This contribution could be beneficial to the management of UiTM in order to enhance and improve their quality of service delivery in the organizations.

\section{Acknowledgement}

This research was supported by the Universiti Teknologi MARA (UiTM) and Ministry of Higher Education. The authors wish to thank Dr. Bahyah Abdul Halim, Professor Wan Abdul Aziz Wan Mohd Amin and Professor Dr. Zainudin Awang for their guidance and advice on preparing this research.

\section{Corresponding Author}

Che Mohd Syaharuddin Che Cob

Faculty of Business \& Management, Universiti Teknologi MARA Kelantan, Machang Campus, 18500 Machang, Kelantan, Malaysia.

Email: syaha793@uitm.edu.my

\section{References}

Ahmad, J., Ather, M. R., \& Hussain, M. (2014). Impact of Big Five personality traits on job performance (Organizational commitment as a mediator). In Management, knowledge and learning international conference (Vol. 1, No. 2014, pp. 571-577).

Ali, A. A. A. M., Kee, D. M. H., Singh, A., Pandey, R., Alhamlan, H., Ahmad, K. M., \& Narayanan, Y. (2020). Does Motivation Improve Employees Job Performance? A Case of Absolute Hotel Services. International journal of Tourism and hospitality in Asia Pasific, 3(3), 9-21.

Awang, Z. (2015). SEM made simple: A gentle approach to learning Structural Equation Modelling: Kuala Lumpur, Malaysia: MPWS Rich Publication

Bass, B. M., \& Avolio, B. J. (1994). Transformational leadership and organizational culture. The International Journal of Public Administration, 17(3-4), 541-554.

Bass, B. M., \& Avolio, B. J. (1990). The implications of transactional and transformational leadership for individuals, team and organizational development. In W.A. Passmore \& R.W. Woodman (eds) Research in organizational change and development (4). Greenwich, CT: JAI Press

Bass, B. M., \& Riggio, R. E. (2003). Transformational leadership.

Borman, W., \& Motowidlo, S. (1997). A theory of individual differences in task and contextual performances. Human Performance, 10 (2), 99-109

Barrick, M. R., Stewart, G. L., \& Mount, M. K. (1991). The big five personality dimensions and job performance: A meta-analysis. Personal Psychology, 44 (1), 1-26 
Bliss, V. (2008). The importance of motivation and clear communication at work. Asperger Syndrome and Employment: Adults Speak out about Asperger Syndrome

Bhatia, S., \& Rawat, B. (2019). Influence of Personality on Performance: Mediating Role of Psychological Strength. Splint International Journal of Professionals, 6(2), 78-86.

Bromfield-Day, D. P. (2002). Employee readiness for self-directed learning and selected organizational variables as predictors of job performance.

Campbell, J. P., McHenry, J. J., \& Wisw, L. L. (1990); Modelling job performance prediction in a population of jobs. Personnel psychology. 43(2), 313 - 333

De Jong, N., Wisse, B., Heesink, J. A., \& Van Der Zee, K. I. (2019). Personality traits and career role enactment: Career role preferences as a mediator. Frontiers in psychology, 10, 1720.

Ellingson, J. E., \& Noe, R. A. (Eds.). (2017). Autonomous learning in the workplace. Taylor \& Francis.

Ford, J. K., Baldwin, T. T., \& Prasad, J. (2018). Transfer of training: The known and the unknown. Annual Review of Organizational Psychology and Organizational Behavior, 5, 201-225.

Goldberg, L. R., Johnson, J. A., Eber, H. W., Hogan, R., Ashton, M. C.., Cloninger, C. R., \& Gough, H. C. (2006). The international approach. Journal of applied Psychology, 86(3), 513-524

Guhr, N., Lebek, B., \& Breitner, M. H. (2019). The impact of leadership on employees' intended information security behaviour: An examination of the full-range leadership theory. Information Systems Journal, 29(2), 340-362.

Holec, H. (1981). Autonomy and foreign language learning. Oxford, UK: Pregamon

Johari, J., Tan, F. Y., \& Zulkarnain, Z. I. T. (2018). Autonomy, workload, work-life balance and job performance among teachers. International Journal of Educational Management.

Klimas, A. (2017). A goal-setting logbook as an instrument fostering learner autonomy. In Autonomy in second language learning: Managing the resources (pp. 21-33). Springer, Cham.

Maneetr \& Thirachaya. (2010). Motivation and working behaviour in frontier Tourism Business of Thailand - Laos. The International Business \& Economics Research Journal; Apr 2010; Vol.9; No.4; pg 105.

Mahlamäki, T., Rintamäki, T., \& Rajah, E. (2019). The role of personality and motivation on key account manager job performance. Industrial Marketing Management, 83, 174184.

Merriam, S. B., \& Baumgartner, L. M. (2020). Learning in adulthood: A comprehensive guide. John Wiley \& Sons.

Mehmood, M. S., Mehmood, A., \& Siddique, M. (2017). Personality traits nexus employee's performance: an application of big five personality dimensions model. Abasyn Journal of Social Sciences-Special Issue: AIC 2016, 101-119.

Motowidlo, S. J., \& Kell, H. J. (2012). Job performance. Handbook of Psychology, Second Edition, 12.

Schmidt, N., Chan, D., \& Hunter. (1992). Personnel Selection: A theoretical approach. Thousand Oaks, CA: Sage Publications

Sekaran, U. (2003). Research Methods for business. New York: John Wiley and Sons (Springer \& Gary Jon, 2011). A study of job motivation, satisfaction, and performance among bank employees. Journal of Global Business Issues; Spring 2011; 5,1;ABI/ 
INFORM Research, pg. 29.

Sudiantha, D., Armanu, A., \& Troena, E. A. (2017). The Effects of Transformational Leadership and Personality on Employee Performance in Nissan Malang Mediated By Organizational Commitment. Russian Journal of Agricultural and Socio-Economic Sciences, (1), 207-215

Syamsir, S. (2020). Competence, Job Satisfaction, Work Motivation, and Job Performance of The Village ("Nagari") Masters in Managing E-Village Finance. International Journal of Advanced Science and Technology, 29(8), 1337-1350.

Vassou, V. (2017). How Self-Regulated Learners Work and Learn: An Interview Study (Master's thesis, University of Twente). 